DANIELA SPINA

\title{
WRITING NATIONAL HISTORY WITHOUT A NATION: THE CASE OF INDO-PORTUGUESE LITERARY HISTORY ${ }^{1}$
}

Goa is a former colony of the long-lasting Portuguese Empire, annexed by India in 1961. After about 450 years of colonial rule, the application of the national model can already be detected in the very first attempts of writing its literary history. Although Goa has never had the political form of a nation, nor is its Portuguese literature actually a concrete literary system, the attempts of writing literary history were and still are presented in such a way that they idealize IndoPortuguese literature as a national literary system. Even if Indo-Portuguese literature was never considered as national literature, this doesn't mean that its actors and readers never felt a sense of belonging to their land or didn't embrace any sort of cultural identity. On the contrary, it can be argued that Indo-Portuguese literature was the written expression of a small Catholic community among other diverse communities such as the Hindu and the Muslim ones. This community, who was speaking and writing in Portuguese despite being a minority, represented the most privileged castes of the Goan society during the years of Portuguese rule. Therefore, this Catholic community had to reimagine itself as a nation able to write its own literary history and, in some cases, to stand against the colonial power.

By means of a review of Indo-Portuguese literary historiography, the purpose of this article is to analyse this corpus for what Linda Hutcheon ${ }^{2}$ states about the persisting attraction of the national model in literary history. In particular, I am interested in ascertaining the many shapes in which the national element appears in the historiography of this literature and how these shapes have changed over time. In this paper, Indo-Portuguese literary historiography is considered as the object of study and not just a one-time reference. This means that the texts selected are treated as active and autonomous sources, with their own epistemological value. Finally, some of the literary histories that I study are not just books, compendiums or dictionaries of literature. The corpus also comprises newspaper articles and essays published in literary and cultural reviews. This choice of incorporating in the corpus of the analysis not just literary history books is due to the very peculiarity of Indo-Portuguese literature and to the long periods of censorship in

\footnotetext{
${ }^{1}$ This work is part of my Ph.D. research in Comparative Studies, funded by FCT - Fundação para a Ciência e a Tecnologia.

${ }^{2}$ Linda Hutcheon, "Rethinking the National Model", in Linda Hutcheon and Mario J. Valdés (eds.), Rethinking Literary History: A Dialogue on Theory, Oxford and New York, Oxford University Press, 2002, pp. 3-50.
} 
Portuguese India, a historical contingency that didn't allow a real book industry to develop in $\mathrm{Goa}^{3}$. Hence, both creative and scientific literature developed irregularly. This historical aspect can also be taken into account when we study texts of literary history. If it is common to find a novel or a collection of tales in the pages of a Goan newspaper, the same holds true for the case of literary history texts.

\section{The persistence of the national model and the case of Indo-Portuguese literary history}

In different stages of the $20^{\text {th }}$ century, the lack of scientific objectivity has been one of the most argued motivations for determining the state of crisis of literary history. To a greater extent, the reason why its epistemological value has been branded as inconsistent was due to the fact that literary history, both as a field of study and as a textual genre, was born in $18^{\text {th }}$ century Europe in order to legitimize the founding narratives of the nation state as the new dominant socio-political construct. Inside the theoretical frame of Postcolonial Studies, the standards of the national model of literary history have been defined as incompatible with the idea of rewriting history from the perspective of the colonized subject. In this sense, it can be argued that literary history has been stigmatized as European and colonial epistemology by many scholars, such as Walter Mignolo ${ }^{4}$ and Sheldon Pollock ${ }^{5}$. Take, for instance, Walter Mignolo's statement that the national model of literary history is "a particular historical version of the colonial model", seen as an epistemic imposition that persists even after the decolonization process. In his opinion, in those cultural contexts affected by a colonial past, in order that their epistemic value be considered as attested, every kind of non-Western cultural categories "have to become similar and assimilated to Western conceptualizations of cultural practices and social organization" ". That is what Mignolo defines as colonial difference, i.e. the peculiarity that non-Western knowledge was built on. $\mathrm{He}$ also underlines that in the case of literary history the colonial difference is even more evident, since the national narratives of this new countries produced a

\footnotetext{
${ }^{3}$ See Vimala Devi and Manuel de Seabra, A Literatura Indo-portuguesa [The Indo-Portuguese Literature], Lisbon, Junta das Investigações do Ultramar, 1971; Sandra Lobo, "Línguas, Culturas Literárias e Culturas Políticas na Modernidade Goesa" ["Languages, Literary Cultures and Political Cultures in Goan Modernity"], Via Atlântica, 2016, 30, pp. 45-63.

${ }^{4}$ Walter Mignolo, "Rethinking the Colonial Model", in Linda Hutcheon and Mario J. Valdés (eds.), Rethinking Literary History, pp. 155-193.

${ }^{5}$ Sheldon Pollock, "Introduction", in Sheldon Pollock (ed.), Literary Cultures in History: Reconstructions from South Asia, Berkeley and Los Angeles, University of California Press, 2003, pp. 1-38.

${ }^{6}$ Walter Mignolo, "Rethinking the Colonial Model", p. 160.

${ }^{7}$ Ibidem.
} 
political discourse very similar to the one that permitted their own subjugation, thus allowing a sort of internal colonialism.

Another interesting position about the European and colonial nature of literary history has been presented by the Sanskrit scholar Sheldon Pollock. In his book Literary Cultures in History: Reconstructions from South Asia (2003), he states that, in the case of the Indian subcontinent literatures, new and non-narrative paradigms of literary history are required. Given the fact that the first Indian literary histories were written by European orientalists in the $19^{\text {th }}$ century, the consequently shaped idea of Indian literary history presents an image of this literature looking unified, written in one single language, namely, the Sanskrit, an old language at the centre of the orientalists' interests at that time. This is the reason why, according to Sheldon Pollock, most of the Indian literary histories written between the $19^{\text {th }}$ and the $20^{\text {th }}$ century paid attention largely to Pali and Pakrit literatures, languages that are closer to the Sanskrit. After the Partition of Pakistan in 1947 and, very importantly, after the setting up of the Sahitya Akademi of India in 1954, this idea of one great monolingual literature was substituted by the idea of a single literature written in many languages. For Pollock, this choice of promoting Indian literature as one yet multilingual was a sort of strategy aimed at placing all literary production under the control of the new Hindu nation state. The author writing in a certain language is not aware of the work of his/her colleagues writing in different ones, which thus prevents the creation of a common literary consciousness, with the nation state having full discretion over what is apt to be promoted and legitimized as national literature ${ }^{8}$. Pollock essentially affirms that, in such a way, the concept of nation acts in the same way as that of literary history, linking a space to one literature and one narration, without querying whether it is literature that determines the space or whether it is the space that creates the conditions under which literature is produced ${ }^{9}$.

The aforementioned national structure of literary history was not only criticized in the field of the Postcolonial Studies, but it also reveals different problems related to the linear and teleological development of literary evolution, mainly in European and American literary histories. Consequently, this has led to a broader problematization of various concepts such as time, period and progress in literature, particularly based on evolutionary conceptions of history ${ }^{10}$. In the course of the $20^{\text {th }}$ century, literary history became a real epistemological problem to be solved. For instance, in the 1960s, although they belonged to different theoretical schools - the first to New Criticism and the second to Reception Theory -, René

\footnotetext{
${ }^{8}$ Sheldon Pollock, "Introduction", p. 10.

${ }^{9}$ Ibidem, pp. 10-11.

${ }^{10}$ See René Wellek, Conceitos de crítica. Translated by Óscar Mendes, São Paulo, Cultrix, 1963; Hans Robert Jauss, A História da Literatura como Provocação à Teoria Literária. Translated by Sérgio Tellaroli, São Paulo, Ática, $1^{\text {st }}$ edition, 1970; David Perkins, Is Literary History Possible?, Baltimore and London, The Johns Hopkins University Press, 1992.
} 
Wellek in the USA and Hans Robert Jauss in Germany agreed on the fact that the age of the narrative model of literary history was definitely over. They argued that this model was a reflection of the triumph of the national spirit based on a teleological evolution of literature, followed by the rise of the nation. In that way, they asked for new methodological and theoretical approaches to literary history, closer to literary criticism and to the reader reception issues. Other critics followed in the 1990s. Among them was David Perkins'essay Is Literary History Possible? (1992), which essentially transformed this epistemological problem into an ontological one, not only by questioning the impossibility of discussing about literary history from inside a national and dominant narrative frame, but also by challenging literary history's own possibility of existence. In Perkins' essay, the teleological form of literary history is not put solely in historical terms, but also in imaginative and emotional ones. For Perkins, various literary forms in narrative literary history are like heroes following a linear path - the chronological periodisation of the literary evolution - towards their own destiny, symbolized by their victory or loss, by the rise and fall of a literary genre, current or author. Therefore, it can be argued that the relation between literary history and its reader is, above all, an empathetic relation. This can be the case of a national literary history, in which the reader is invited to recognise him/ herself in the collective narration of a national history.

Despite all these critics, some scholars still argue that there is still a certain attraction for the narrative and national model, even in the $21^{\text {st }}$ century, which leads me to think about the aforementioned problem of teleology as a congenital defect of literary history and, accordingly, of the national model as an irreplaceable contingency. The work of researchers such as Linda Hutcheon (2002) has shown that the signifier of the national does not refer only to national identities or to a particular space understood as existing inside some geographical borders, but that it denotes, above all, a way of conceiving literature and a way of writing its history. According to Linda Hutcheon

Interestingly, the new literary histories often adopt the exact developmental, teleological narrative model used by nation-states: that is, they too assume an implicitly natural process at work which is shaped by purpose and design, wherein literature is directly related to the specific "end" or telos of cultural legitimation".

In other words, the literatures that were excluded by this national model unexpectedly opt for the same structure and parameters. Feminist literatures, gay and queer literatures, diasporic literatures, postcolonial literatures are just a few of the many examples provided by Hutcheon, who justifies the choice of the national model in accordance with the needs and the collective agendas of those communities and subcultural groups, thus associating such a choice with a certain type of political interventionism. In fact, what Hutcheon advocates is that the

\footnotetext{
${ }^{11}$ Linda Hutcheon, "Rethinking the National Model”, p. 5.
} 
continuous attraction to the national model can be explained by the need to look at the foundational moment of specific literatures and afterwards, starting from that point, to trace a utopian, linear and interventionist path that would be able to contribute to the legitimation of those literatures and/or the ideologies that might be hidden behind them.

Speaking about Indo-Portuguese literature, the purpose of this paper is to show how the national model worked and still works in the case of the writing - and rewriting - of Indo-Portuguese literary history. However, before getting to the heart of my argument, it is necessary to provide some historical and contextual information to those readers that could be unfamiliar with this literature:

- Goa, together with Daman and Diu, have formed the Estado da Índia Portuguesa (State of Portuguese India) since 1556. Those lands were liberated by the Indian Union army in 1961, after a war initiated by the Goan freedom fighters;

- to this day there is no Portuguese-language literary system in Goa. This is because the Portuguese language was eradicated in a long institutional process which began in 1962, just after the end of colonialism. As a response to that, the local authorities prioritised the promotion of the local language, Konkani. The latter was repressed during the Portuguese rule;

- this literature can be called Indo-Portuguese literature or Goan literature in Portuguese. The two terms are sometimes used as synonyms and can be found with two distinct meanings. Usually, the usage of those different terms changes in accordance with the theoretical approach employed. Currently, many scholars applying a Postcolonial Studies perspective argue that the name "Goan literature in Portuguese" can avoid the image of subordination to the colonisers' culture. Contrariwise, other scholars state that the connotation Indo-Portuguese literature can be considered more accurate, since this literature was essentially produced by authors who were part of the Catholic community. In addition, most of the authors representing this literature defined themselves as Indo-Portuguese writers. For the purposes of this article, the two terms will be used as synonyms, explaining, case by case, why Goan literary historians used one terminology or another in their literary histories.

\section{Goan and Indo-Portuguese literary history between the $19^{\text {th }}$ and the $20^{\text {th }}$ century}

The first text under scrutiny is entitled "Duas Palavras sobre o Progresso Literário em Goa" ["Two Words on Literary Progress in Goa"] ${ }^{12}$, by the Brahmin intellectual Jacinto Caetano Barreto Miranda. The text was published in Lisbon in the Revista Contemporânea de Portugal e Brasil [Contemporary Review of Portugal and Brazil], but was written in Margão (Salcete, South Goa) on $20^{\text {th }}$ December 1864. The author of this essay intends to explore the idea of literary

\footnotetext{
${ }^{12}$ All the translations are mine, unless otherwise indicated.
} 
progress in the Goan landscape, founding his analysis on the assessment of different moments in the colonial history of Goa. As Sandra Lobo ${ }^{13}$ points out, the publication of this essay in a Portuguese magazine needs to be contextualized within the transnational framework in which Goan modernity has emerged. In this context, we have not only to consider the fruitful contribution of many Goan intellectuals living abroad, but also the fact that the Portuguese Liberal Revolution and the constitutional laws (1820-1821) had a considerable influence on the political and cultural life of the colony and, above all, on the struggle of the local elites, the Catholic Brahmin and Chardó, in their quest for power. It is important to underline that those elites took advantage of the periodical press for propagandistic aims. The press was established in Goa in 1822, after 67 years of censorship (17541821). It was first under the colonial administration of the Imprensa Nacional and later run by locals of both Catholic elite groups.

Barreto Miranda traced the evolutionary path of this press that essentially marks the beginning of the history of literature in Goa. The structure of the article follows a linear path and the author uses a narrative style of writing. The foundational moment is the creation of seminaries and colleges at the time of the first Jesuit evangelisation campaigns in the 16th century; the peak moment is signaled by the end of press censorship in 1821, which is followed by a remarkable boom in periodical publications. For Miranda, literary progress plays an important part in a broader process, reminding us that literary progress can be initiated by just one group of engaged men in a position to influence the political and cultural emancipation of their land. Specifically, Miranda was referring to the Brahmin elite itself and to the action of Bernardo Francisco da Costa, the founder of the first private printing press in Goa, and to the publication of $O$ Ultramar [The Overseas], the first newspaper ever printed there in 1859. For Barreto Miranda, the foundation of $O$ Ultramar represents the apogee of literary progress in Goa, and Bernardo Francisco da Costa embodies a kind of messianic figure, equipped with the right skills to lead his land to successful emancipation. He emphazises the fact that the Brahmin newspaper can be seen as "the touchstone", "the patriarch of the newspapers of Goa", "the temple", "the forum"14. Its founder is the one who "figured out that some of the groundwork of progress in the country lay in the introduction of the press, and once he returned to his country, he did not rest until he saw his printing press set up" 15 .

Before evoking the figure of Bernardo Francisco da Costa, who was the representative of Goa, Daman and Diu in the Cortes (Portuguese Congress), Barreto Miranda writes about the "difficulties aimed at stifling the yell of our

\footnotetext{
${ }^{13}$ Sandra Lobo, "Línguas, Culturas Literárias e Culturas Políticas".

${ }^{14}$ Jacinto Caetano Barreto Miranda, "Duas Palavras sobre Progresso Literário em Goa" ["Two Words on Literary Progress in Goa"], Revista Contemporanea de Portugal e Brasil, 1864, 11, p. 590.

${ }^{15}$ Ibidem, p. 589.
} 
aspirations"16, thus referring to the ban of the Imprensa Nacional on literary production, despite the end of the censorship era. The telos of this historiographical text can be linked to the assertion that the Catholic Brahmin community can be seen as a bearer of liberal ideals suitable for bringing Goa to a state of political and cultural autonomy. So, in Barreto Miranda's essay, the values supported by the national narrative are substituted by the ones of the Brahmin elite, maintaining the narrative structure of a national literary history and the idea of literary evolution conveyed by the image of literary progress.

The second text presented here is a book published in Bombay in 1926, entitled Literatura Indo-Portuguesa: Figuras e Factos [Indo-Portuguese Literature: Figures and Facts]. It was written by Vicente de Bragança Cunha, a Goan intellectual and journalist interested in politics, member of the Chardó elite and brother of Tristão de Bragança Cunha, a committed nationalist and one of the most active personalities of the Goan anticolonialist movement of Marxist orientation. In spite of his family links, Vicente de Bragança Cunha had a very different political position from his brother's. This can be traced in his writings, which exhibit great sympathy for the Portuguese presence in Goa and, at the same time, great esteem for the Portuguese monarchy, abolished in 1910. During the Republican struggle in Portugal, Bragança Cunha published various articles in different English magazines and newspapers, reporting to the English audience on the political situation in the metropole. In those articles, one can see some of his political positions later reaffirmed in his literary history, such as the belief in the existence of a large IndoPortuguese nation, in which the Indian enclave would be only an extension of Portugal.

Vicente's literary history was first published in the newspaper A India Portugueza [The Portuguese India], a journal affiliated with the Chardó elite, whose director he was between 1919 and 1922 . The chapters that make this literary history were taken from articles published between April and June 1919, in a column entitled "Literatura Indo-Portuguesa" ["Indo-Portuguese Literature"]. On comparing the various editions of the column with the unified edition of 1926, one can note that the author managed a direct "cut and paste" operation: he did not reproduce the articles in the order of publication in the newspaper, but devised a new narrative plot in which they followed a linear order. Along with this makeover, the choice of collecting and publishing the unified book in 1926 is probably due to Vicente's awareness of the need to edit a Goan literary history. He probably knew that the format of a literary history book could lend more legitimacy to the ideas contained in his articles, allowing the use of his book even in schools or at university. Therefore, in this case, the narrative structure of a literary history seems to support the idea of an Indo-Portuguese national literature.

${ }^{16}$ Ibidem, p. 589. 
However, it can be noted that when Vicente is using the term "IndoPortuguese", he refers to a sort of identity-pound space, where the culture of the metropole meets the culture of the colony. In his opinion, poets, novelists, journalists and historians have a civil obligation and a moral duty to nourish the Portuguese culture and preserve it as common heritage. For instance, the first chapter of the book is dedicated to the figure of Moniz Barreto, an intellectual born in Goa, in a family of descendentes ${ }^{17}$. He emigrated to Portugal as an adolescent and is considered to be the originator of Portuguese literary criticism. The chapter opens with the following sentence: "Portuguese traditions were never lost in India" ${ }^{18}$. This statement leads the narrative plot of the literary history book. In each chapter of this particular book Vicente stresses the importance of keeping the Portuguese legacy of Goa alive. For Bragança Cunha, Moniz Barreto embodies the right attitude allowing the culture of the metropole to be embraced by Goans.

The second chapter of Vicente's book is dedicated to Indianist poetry. In this chapter, the reader can understand how the Indian component that broadly characterizes the work of that generation of poets influenced by Vedic culture is subordinated to the Portuguese element. Braganca Cunha writes about the legacy of pre-Lusitanian civilizations and their influence on the development of those poets and, at the same time, he tries to explain their attraction to it. The latter is being characterized as "hereditary forces of which they are not fully aware"19, therefore implying the existence of some irrational meanings justified by ethnic arguments. On the contrary, the heritage of the metropole is constructed on real values addressed by Portuguese historiography, as mentioned in the fifth chapter of the book.

In the light of the above, the national model is evident not only in the narrative structure, but primarily in the very idea of Indo-Portuguese national literature and its politicisation, used as a broader apparatus that affirms a specific cultural identity. The Chardó elite, to which Bragança Cunha belonged, was always closer to the colonial power, this closeness being a strategy to face the strength of the Brahmin elite (Lobo 2013). In fact, although there is no fully justified acclamation for the Chardó caste in the book, there are many attacks against members and historical figures of the Brahmin, whose work Vicente criticises. For example, the Brahmin Bernardo Francisco da Costa, overpraised in Jacinto Caetano Barreto Miranda's essay, is disapproved of by Vicente de Bragança Cunha in his book.

\footnotetext{
${ }^{17}$ The social group of descendentes was a Goan elite comprising families of direct descendants from the Portuguese settlers.

18 Vicente de Bragança Cunha, Literatura Indo-portuguesa: Figuras e Factos [Indo-Portuguese Literature: Figures and Facts], Bombay, author's edition, 1926, p. 1.

${ }^{19}$ Ibidem, p. 8.
} 


\section{Literary history in the $20^{\text {th }}$ century and after colonialism}

The third text analysed is Esboço da História da Literatura Indo-Portuguesa [An Outline of the History of Indo-Portuguese Literature], a book written by Father Filinto Cristo Dias in 1963. Filinto Cristo Dias was a professor of Portuguese language and literature at the Seminary of Our Lady of Saligão in North Goa. He wrote his literary history both for pedagogical purposes and out of his own intellectual interest. Dias is one of the most vehement promoters of a local, autonomous and Portuguese-written literature, and can be considered among the defenders of this language at one of its most critical moments, i.e. after 1961. This literary history can be considered the first to work with a clearer subdivision into periods and literary genres and the first to provide a definition of the concept of Indo-Portuguese literary history. As such, it aims to establish and comply with criteria of inclusion and exclusion. This book presents a linear narrative and storyline, in which language and literature are exclusively associated with the expression of the unique cultural identity that characterises the Indo-Portuguese community. Thus, the idea of literary history present in this book can be seen as an heir to the $19^{\text {th }}$ century romantic tradition, in which the teleological meaning points to the statement of one fact: the indispensability of the Portuguese legacy for the survival of an intellectual class among the Catholic Goans. In this case, the nation is represented by the whole Catholic Indo-Portuguese community.

According to Filinto Cristo Dias

the recording and study of all these creations belong to the History of the IndoPortuguese Literature that can be defined as a review and critique of all the works in verse and prose written by the Goans who used Portuguese to express their ideas and feelings ${ }^{20}$.

The definition of the concept of Indo-Portuguese literary history probably comes from the author's need to contextualize his book within a specific scientific field. Dias knew that Goan literature written in Portuguese was something on the verge of extinction and writing a canonical literary history could therefore be a way to avoid or delay that process of eradication.

Esboço da História da Literatura Indo-Portuguesa wasn't fully edited before 1963, but it was published in different articles in the Boletim Eclesiástico da Arquidiocese de Goa [Ecclesiastical Bulletin of the Archdiocese of Goa] from 1957 to 1963. Apparently, the structure of the book shows that it was originally conceived as a volume from the beginning. For instance, by comparing the first "Nota Preambular" ["Preliminary Note"], published in the Boletim n 6 in 1957, and the "Advertência Preambular" ["Preliminary Warning"] published in the

\footnotetext{
${ }^{20}$ Filinto Cristo Dias, Esboço da História da Literatura Indo-portuguesa [An Outline of the History of Indo-Portuguese Literature], Bastorá, Tipografia Rangel, 1963, p. 3.
} 
unified edition of 1963, we notice that the two texts present important differences, due to the political changes that took place in Goa after 1961. Accordingly, by comparing the two introductions, a potential reader might conceive of two different meanings of the story of this literary history: one more closely related to its process of writing and the other more closely related to the author's attempt to publish his work as a single volume. Nevertheless, Filinto Cristo Dias' literary history is marked by a romantic orientation. He describes the Portuguese language as the language chosen by Goans to express their feelings. Thus, he often uses the verb pertencer (belong) and the noun pertença (belonging) to refer to the relation between authors, language and literature. That is undoubtedly a request for Goans to reflect on the future of the Portuguese language in Goa, remembering their ties with Portuguese culture before it is too late.

The fourth text presented is entitled A Literatura Indo-portuguesa [The IndoPortuguese Literature]. It was written by the Goan writer Vimala Devi and her husband, the Portuguese writer Manuel de Seabra. This literary history was published in Lisbon in 1971 and was financed by the Junta das Investigações do Ultramar (Overseas Investigations Board), an institution conducting scientific research in the colonies. Although 1971 marks the $10^{\text {th }}$ anniversary of the annexation of Goa by the Indian Union, the book reproduces the rhetoric of assimilationist politics propagated by the Portuguese Empire during its last twenty years. In particular, the argument on which this literary history has been written reminds the Luso-tropicalism theory developed by the Brazilian sociologist Gilberto Freyre (1953). The latter advocates for a soft interpretation of Portuguese colonialism based on racial miscegenation. In this sense, Vimala Devi and Manuel de Seabra basically rely on the rhetoric of Luso-tropicalism in order to justify the very idea of a hybrid literature testifying for four centuries of Portuguese philanthropic actions and initiatives in the East. Despite the closeness of this position to colonial ideology, it determines the teleological mark of this work, published during the Colonial War in Africa (1961-1974). Still, the book is considered a complete repository of bibliographical information on the Goan literature, and it is also the first book to have problematised this literature using the methodological approach of literary criticism. It is very likely that the adherence to Luso-tropicalism was due to the fact that the research had been funded by a colonial institution.

Furthermore, the book is divided according to literary genres and the periodisation is internal to the chapters. This means that each chapter narrates the history of one genre in the literature of Goa. However, there are a few chapters at the beginning of the book that propose a general introduction to the history of this literature, showing how the Portuguese started to write about Goa and how the Goans started to write in Portuguese. According to the two authors, IndoPortuguese literature starts with the Discoveries and the beginning of Catholic evangelisation. At the end of the book, Vimala Devi and Manuel de Seabra dedicate the last chapter to Indo-Portuguese poetry, which is considered the highest 
expression of Goan genius and the best example of cultural and literary hybridity. In canonical and teleological literary histories, the genre that is most representative of the literature, or of the community or identity behind it is usually discussed at the end of the book, as it generally means the end of the evolution of that literature and the most perfect manifestation that particular literature could showcase. Taking into account the institutional support for the book, the sophisticated Goan poetry written in Portuguese can be considered an ideal case that reminds the readers how Indo-Portuguese literature can be interpreted as the result of the fusion between the metropole and its colony. Consequently, this stance presents and enhances a sort of humanitarian attitude displayed by the Portuguese. Therefore, if a reader of this literary history acknowledges the political discourse it carries, he/she might be able to understand that the idea of nation here is very similar to that of Vicente de Bragança Cunha's Indo-Portuguese national literature. However, bearing in mind the tragic conditions to which Portuguese culture and language were subjected in Goa after 1961, Vimala Devi and Manuel de Seabra declare in the afterword of the book that their hopes for this literature not disappearing completely lie with the diasporic writers in Portugal. Regardless of the future of Portuguese language in Goa, Indo-Portuguese literature represents, for the two authors, something concrete that continues to exist through the work of Goan authors who have emigrated to Portugal, no matter what their political positions may be. At the end of the book, it seems that Goan literature is already a nation, a literary community of which Devi and Seabra, as writers and critics, are part.

Finally, as David Perkins ${ }^{21}$ stated in his essay, the path travelled by literature in a national and narrative literary history is very similar to the path of the hero passing through different stages, experiencing victories and losses. Similarly, IndoPortuguese literature in Devi and Seabra's book goes on a path of glory and falls, experiencing total rejection at the end of its history.

As final examples, I would like to mention two more recent contributions to Goan literary history, both written outside Goa. The first book is entitled Literatura Goesa em Português nos Séculos XIX e XX: Perspetivas Pós-coloniais e Revisão Critica [Goan Literature in Portuguese in the 19th and 20th Century: Postcolonial Perspectives and a Critical Review] written in 2012 by the Portuguese researcher Joana Passos. The second one is a book chapter entitled "A História da Literatura Goesa de Língua Portuguesa. Uma Questão de Designação" ["The History of Goan Literature in Portuguese. A Question of Naming"], written in 2014 by Hélder Garmes and Paul Melo e Castro, two researchers working on the Pensando Goa (Thinking Goa) project at the University of São Paulo (Brazil). The first is a literary history and the second one is a critical essay about rewriting Goan literary history. Both texts share the theoretical approach of Postcolonial Studies and agree with the idea that Goan literary history essentially covers only the $19^{\text {th }}$

${ }^{21}$ David Perkins, Is Literary History Possible? 
and $20^{\text {th }}$ century. That period determines the departure point that marks the separation from Portuguese culture and initiates the original evolution of Goan literature. Their proposals follow different criteria of inclusion, according to which all previous literary production must be excluded, since it belongs to the coloniser's representation sphere. Significantly, the two texts also call for a radical change of the name "Indo-Portuguese literature" into "Goan literature in Portuguese" or "Goan literature of Portuguese expression", since the latter would be less dependent on Portuguese culture.

It also makes this literature similar to other literatures written in the same language, such as the African literatures of Portuguese expression, for example. This group of literatures is often approached using the theory of "the macrosystem of national literatures in Portuguese" ${ }^{22}$, that is mostly applied to the Brazilian and Lusophone African Literatures. Hélder Garmes and Paul Melo e Castro ${ }^{23}$ urge that Goan literary history should be studied from within the same comparative theoretical frame, since it shares those literatures' past of colonialism and subordination to the coloniser's culture. The main problematic issue of the "macrosystem of national literatures in Portuguese" is that those literatures are considered to be national ones. Therefore, they are expression of national feelings and national literary communities. This doesn't apply in the case of IndoPortuguese literature, since it only represents a Catholic minority, no matter how powerful. In other words, here the idea of nation is replaced by that of community of literatures and the historiographic criteria proposed are not so different from those that have caused the epistemological crisis of literary history: origin, inclusion and exclusion criteria, evolution, direction and purpose - the last one better expressed by telos. Thus, the aim of this historiographical revision is an application of the national model of literary history, where nation is replaced by the idea of community of Lusophone literatures.

\section{Conclusions}

Despite the national turn to new proposals of rewriting Indo-Portuguese literary history, the work of these scholars brings to light a literature that has fallen into oblivion after the 1970s. Therefore, we can link their approach to the issue of

22 Benjamin Abdala Junior, De Vôo e Ilhas: Literatura e Comunitarismos [Flights and Islands: Literature and Communitarianism], São Paulo, Ateliê Editorial, 2003; Benjamin Abdala Junior, Literatura, História e Política: Literaturas de Língua Portuguesa no Século XX [Literature, History, and Politics. The Literatures in Portuguese Language in the $20^{\text {th }}$ Century], São Paulo, Ateliê Editorial, 2007.

${ }^{23}$ Helder Garmes and Paul Melo e Castro, "A História da Literatura Goesa de Língua Portuguesa. Uma Questão de Designação" ["The History of Goan Literature in Portuguese. A Question of Naming"], in Benjamin Abala Junior (ed.), Estudos Comparados. Teoria, Crítica e Metodologia [Comparative Studies. Theory, Literary Critique, and Methodology], São Paulo, Ateliê Editorial, 2014, pp. 211-242. 
literary emergence. Arguably, Linda Hutcheon's thought about the preference for the narrative and national model is also applicable to the case of the literary history of Goa and by extension to the comparative studies of literary histories of Portuguese expression. As Hutcheon says,

Again, despite the dangers, the adoption of this model may signal neither historical-theoretical naiveté nor conservative nostalgia on the part of postcolonial literary historians. Instead, it may be a canny borrowing of the structural power of that earlier national(ist) narrative of a history of progress, but now used to new but equally political interventionist ends. At the risk of generalizing, perhaps it is worth noting that the conditions that determine national identity may have not changed quite as much over the centuries as we would like to think. It may also be a question of using the most effective model to compete with the dominant one ${ }^{24}$.

In this way, a reasonable question is raised about legitimisation and literary emergence that prompts literary historians to still opt for the national model. At a deeper level, if scholars try to rewrite Indo-Portuguese literary history by choosing the national model, they could underestimate most of the problems that characterize this specific type of literature, such as the absence of continuity and the abrupt interruption it suffered after 1961. In this light, the historian Sandra Lobo $^{25}$ proposes substituting the term Goan literature with Goan literary cultures. Consequently, she emphasizes the plurality of different voices and languages that make up Goan history, paying more attention to the relations and interconnections between cultural expressions that were eclipsed by the colonial regime. Similarly, the growing theoretical field of Comparative Literary History replaces the concept of history of literature with that of history of literary cultures, a concept that refers to a spatial understanding of literary history, not to one solely based on the notions of time, period and evolution. This new turn in scientific inquiry could allow a deeper and more critical reflection on the possibility of rewriting a new version of literary history that takes more organically into account all the languages in which Goans wrote and still write, such as Konkani, Maratha, English and, of course, Portuguese. This might assist literary history in overcoming and moving beyond a colonial past without erasing the marks of its brutality.

\section{BIBLIOGRAPHY}

CUNHA, Vicente de Bragança, Literatura Indo-portuguesa: Figuras e Factos [Indo-Portuguese Literature: Figures and Facts], Bombay, author's edition, 1926.

DEVI, Vimala. SEABRA, Manuel de, A Literatura Indo-portuguesa [The Indo-Portuguese Literature], Lisbon, Junta das Investigações do Ultramar, 1971.

\footnotetext{
${ }^{24}$ Linda Hutcheon, "Rethinking the National Model", p. 15.

${ }^{25}$ Sandra Lobo, "Línguas, Culturas Literárias e Culturas Políticas".
} 
DIAS, Filinto Cristo, Esboço da História da Literatura Indo-portuguesa [An Outline of the History of Indo-Portuguese Literature], Bastorá, Tipografia Rangel, 1963.

FREYRE, Gilberto. Um Brasileiro em Terras Portuguesas [A Brazilian in Portuguese Lands], José Olympio, Rio de Janeiro, 1953.

GARMES, Helder and CASTRO, Paul Melo e, "A História da Literatura Goesa de Língua Portuguesa. Uma Questão de Designação" ["The History of Goan Literature in Portuguese. A Question of Naming"], in Benjamin Abala Junior (ed.), Estudos Comparados. Teoria, Crítica e Metodologia [Comparative Studies. Theory, Literary Critique, and Methodology], São Paulo, Ateliê Editorial, 2014, pp. 211-242.

HUTCHEON, Linda, "Rethinking the National Model", in Linda Hutcheon and Mario J. Valdés (eds.), Rethinking Literary History: A Dialogue on Theory, Oxford and New York, Oxford University Press, 2002, pp. 3-50.

JAUSS, Hans Robert, A História da Literatura como Provocação à Teoria Literária. Translated by Sérgio Tellaroli, São Paulo, Ática, $1^{\text {st }}$ edition, 1970.

JUNIOR, Benjamin Abdala. Literatura, História e Política: Literaturas de Língua Portuguesa no Século XX [Literature, History, and Politics. The Literatures in Portuguese Language in the $20^{\text {th }}$ Century], São Paulo, Ateliê Editorial, 2007.

JUNIOR, Benjamin Abdala, De Vôo e Ilhas: Literatura e Comunitarismos [Flights and Islands: Literature and Communitarianism], São Paulo, Ateliê Editorial, 2003.

LOBO, Sandra, "Línguas, Culturas Literárias e Culturas Políticas na Modernidade Goesa" ["Languages, Literary Cultures and Political Cultures in Goan Modernity"], Via Atlântica, 2016, 30, pp. 45-63.

LOBO, Sandra, O Desassossego Goês: Cultura e Política em Goa do Liberalismo ao Acto Colonial [Goan Restlessness: Goa Culture and Politics from Liberalism to the Colonial Act], Ph.D. diss., Universidade Nova de Lisboa, 2013.

MIGNOLO, Walter, "Rethinking the Colonial Model", in Linda Hutcheon and Mario J. Valdés (eds.), Rethinking Literary History, pp. 155-193.

MIRANDA, Jacinto Caetano Barreto, "Duas Palavras sobre Progresso Literário em Goa" ["Two Words on Literary Progress in Goa"], Revista Contemporanea de Portugal e Brasil, 1864, 11, pp. 583-593.

PASSOS, Joana, Literatura Goesa em Português nos Séculos XIX e XX: Perspectivas Pós-coloniais e Revisão Critica [Goan Literature in Portuguese in the 19th and 20th Centuries: Postcolonial Perspectives and Critical Review], Ribeirão, Editora Húmus, 2012.

PERKINS, David, Is Literary History Possible?, Baltimore and London, The Johns Hopkins University Press, 1992.

POLLOCK, Sheldon, "Introduction", in Sheldon Pollock (ed.), Literary Cultures in History: Reconstructions from South Asia, Berkeley and Los Angeles, University of California Press, 2003, pp. 1-38.

WELLEK, René, Conceitos de crítica. Translated by Óscar Mendes, São Paulo, Cultrix, 1963.

\section{WRITING NATIONAL HISTORY WITHOUT A NATION: THE CASE OF INDO- PORTUGUESE LITERARY HISTORY}

\section{(Abstract)}

This article aims to make a retrospective enquiry into the Indo-Portuguese literary history by looking at the particular part of the literature that was written by the Catholic community of Goa during the Portuguese rule in India. Although Indo-Portuguese literature does not represent national identity or national history, this article shows the way in which a national and narrative model has been followed by most of the authors writing about the literary history of Goa. It can be seen that concepts such as 
elite, caste and community substitute the concept of nation, but without, in fact, replacing the ideological and theoretical basis on which the national model of literary history was conceived in the $18^{\text {th }}$ and $19^{\text {th }}$ centuries in Europe. According to Linda Hutcheon (2002), the national and narrative type of literary history is also preferred even by Postcolonial literatures and by all those literatures that were excluded from the narratives of the Nation-State, referring to this choice as a political one. This theoretical frame will be the basis on which I built my argument.

Keywords: Indo-Portuguese literary history, Goa, national and narrative model, Postcolonial literatures, elite, caste, community, Portuguese colonialism.

\section{SCRIIND ISTORIA NAȚIONALĂ INN ABSENȚA NAȚIUNII: CAZUL ISTORIEI LITERARE INDO-PORTUGHEZE (Rezumat)}

Lucrarea propune o revizitare a istoriei literare indo-portugheze prin focalizarea pe literatura scrisă de comunitatea catolică din Goa în timpul colonizării portugheze a Indiei. Cu toate că literatura indoportugheză nu reflectă o identitate sau o istorie națională, acest articol dezvăluie că tocmai modelul național și narativ-teleologic a fost cel urmat de autorii care au scris despre istoria literară a Goa. Concepte precum elită, castă ori comunitate au înlocuit ideea de națiune, însă baza ideologică și teoretică a rămas tot scenariul istoriografic național instituit în Europa secolelor XVIII şi XIX. Potrivit Lindei Hutcheon (2002), modelul național și narativ-teleologic al istoriei literare a fost preferat chiar şi de literaturile postcoloniale ori de acelea care nu au putut avea acces la narațiunile identitare ale statului-național. Respectiva opțiune - căreia Hutcheon îi denunță motivațiile politice constituie cadrul teoretic în care sunt dezvoltate argumentele acestui articol.

Cuvinte-cheie: istorie literară indo-portugheză, Goa, modelul naţional și narativ, literaturi postcoloniale, elită, castă, comunitate, colonialism portughez. 